\title{
Genetic profile and clinical application of chromosomal microarray in children with intellectual disability in Hong Kong
}

\author{
Purdy YT Chan, HM Luk, Florence MY Lee, Ivan FM Lo *
}

\begin{abstract}
A B S T R A C T
Introduction: Chromosomal microarray (CMA) is recommended as a first-tier genetic investigation for intellectual disability (ID), developmental delay, or autism spectrum disorder due to its higher diagnostic yield with respect to conventional karyotyping. The aim of the present study was to investigate the genetic profile and diagnostic yield of CMA in children with moderate, severe and profound ID.
\end{abstract}

Methods: A pilot cross-sectional study was performed by the Child Assessment Service and the Clinical Genetic Service in Hong Kong from July 2016 to June 2017. Children with unexplained ID were recruited for CMA testing by an expedited referral pathway. Children who were existing clients of the Clinical Genetic Service were also recruited.

Results: Of 225 children included in this study, $68(30.2 \%)$ had genetic diagnoses. Among the 138 children who underwent CMA testing, 53 (38\%) children were referred to the Clinical Genetic Service by the expedited referral pathway. The respective diagnostic yields of CMA in moderate, severe, and profound ID were $8.7 \%, 17.6 \%$, and $23.5 \%(\mathrm{P}<0.05)$.
Children with dysmorphic features demonstrated a much higher yield from CMA $(45.8 \%$ vs $4.4 \%$, $\mathrm{P}<0.05)$.

Conclusion: The overall diagnostic yield (11.6\%) of CMA in this cohort is comparable with that of other international cohorts. This further supports the use of CMA as a first-tier genetic investigation for children with ID, developmental delay, or autism spectrum disorder, particularly for those with severe disease.

\section{Hong Kong Med J 2018;24:451-9} DOI: 10.12809/hkmj187260

${ }^{1}$ PYT Chan, FHKCPaed, FHKAM (Paediatrics)

${ }^{2}$ HM Luk, MD (HK), FHKAM (Paediatrics)

FMY Lee, FHKCPaed, FHKAM (Paediatrics)

2 IFM LO *, FHKCPaed, FHKAM (Paediatrics)

Child Assessment Service, Department of Health, Hong Kong

Clinical Genetic Service, Department of Health, Hong Kong

* Corresponding author: con_cg@dh.gov.hk

Approximately one-third of children with more severe forms of intellectual disability exhibited a genetic condition, as determined by chromosomal microarray.

- The diagnostic yield of chromosomal microarray testing increases with the severity of intellectual disability, and with the severity of dysmorphic features.

Implications for clinical practice or policy

- The expedited mechanism, if extended to younger children with developmental delay (with or without autism spectrum disorder), may avoid unnecessary investigations in children, improve the efficiency of service delivery, and reduce societal cost.

\section{Introduction}

Intellectual disability (ID) is estimated to affect $1 \%$ to $3 \%$ of the population in Western societies. ${ }^{1}$ It is almost two-fold greater in prevalence in lowand middle-income countries, compared with high-income countries. Importantly, the General Household Survey in 2014 showed the prevalence rate of ID to be approximately $1.0 \%$ to $1.4 \%$ in Hong Kong. ${ }^{2}$

Intellectual disability is defined as 'significant limitations both in intellectual functioning and in adaptive behaviour, as expressed in conceptual, social, and practical adaptive skills. ${ }^{3}$ These difficulties are evident above the age of 18; ID is indicated by an intelligence quotient (IQ) of approximately two standard deviations (SD) or more below the population mean (IQ $\leq 70)$ on the IQ test.

Developmental delay (DD) describes the developmental level of a child, typically $<5$ years old, who is substantially below the average standard of his peers. Global DD is defined as a significant delay in two or more domains: gross motor, fine motor, language, cognitive, social, or activities of daily living. Significant delay refers to scores $>2$ SD below the mean on norm-referenced age-appropriate developmental tests. ${ }^{4}$ 


\section{香港智力障礙兒童之遺傳成因及基因晶片研究}

陳英婷、陸浩明、李敏尤、盧輝文

引言：由於基因晶片（CMA）比傳統染色體檢查（karyotype）對人 類基因體的數量變化檢測分析更詳盡及有更高的診斷率, CMA因此 被建議為智力障礙、發展遲緩或自閉症譜系障礙患者的第一線遺傳驗 測方法。本研究旨在檢視中度、嚴重和極嚴重智力障礙的遺傳成因及 CMA於兒童智力障礙的臨床應用

方法：衞生署轄下兒童體能智力測驗服務與醫學遺傳服務於2016年7 月至2017年6月期間進行一項先導計劃, 對兒童體能智力測驗服務轄 下患有智力障礙但原因不明的兒童進行CMA檢測, 並對醫學遺傳服務 同期合資格的兒童之基因結果數據進行研究。

結果：本研究納入的 225 名兒童中, 68 人 $(30.2 \%)$ 被診斷出遺傳成 因。於接受 CMA檢測的138名兒童中, 53名（38\%）兒童是通過先導 計劃的驗測而縮短確診時間。CMA於中度、嚴重和極嚴重智力障礙的 確診率分別為 $8.7 \% 、 17.6 \%$ 和 $23.5 \%(\mathrm{P}<0.05) \circ \mathrm{CMA}$ 於具有畸形特 徵的兒童的確診率較高（ $45.8 \%$ 對 $4.4 \%, \mathrm{P}<0.05)$

結論：CMA的總體診斷率（11.6\%) 與其他國際研究相若。這進一步 支持CMA作為患有智力障礙、發展遲緩或自閉症譜系障礙兒童, 尤其 是嚴重患者的第一線遺傳驗測方法。
In 2015 and 2016, more than 3000 children per year were diagnosed with DD by the Child Assessment Service (CAS). A study conducted in 2003 to 2004 showed that $80 \%$ of children with significant delay and $30 \%$ of children with borderline delay were later confirmed to exhibit ID at an older age. ${ }^{5}$ Overall, $30 \%$ of children with ID had a co-morbid diagnosis of autism spectrum disorder (ASD).

The aetiology of ID is complex. While milder forms of ID are suspected to typically result from the interplay of genetic and environmental factors, ${ }^{6}$ biological causes, particularly genetic causes, are often identified in children with significant cognitive delays (IQ <50). ${ }^{4}$ Rauch et $\mathrm{al}^{7}$ studied 670 subjects, generally $<6$ years of age, with ID: in $39.5 \%$, ID was related to a genetic cause; in $1.3 \%$, it was due to an acquired or environmental cause; and in $50 \%$ to $60 \%$, it did not exhibit a known aetiology.

Chromosomal microarray (CMA) or array comparative genomic hybridisation, is recommended by many international professional organisations as a first-tier genetic investigation for children with unexplained DD, ID, or ASD. $4,8,9$ Compared with conventional karyotyping, CMA is able to detect copy number variants (CNVs) with much finer resolution and is not reliant on staining and visual resolution limits. In 2010, a review of 33 published studies-involving 21698 patients with DD, congenital anomalies, or autism-found the diagnostic yield of CMA to be $15 \%$ to $20 \%$ across all studies, compared with $3 \%$ for the standard G- banded karyotype. ${ }^{9}$ In a group of 94 patients with no symptoms other than ID, and no clear dysmorphic features, the diagnostic yield was $6.4 \%{ }^{8}$ According to the American Academy of Neurology guideline in 2011, CMA testing was abnormal in approximately $7.8 \%$ of patients with global DD or ID. The yield was higher (10.6\%) in those with syndromic features. ${ }^{8}$

Children with ASD who had co-morbid ID were more likely to yield molecular diagnoses. ${ }^{10}$ Approximately $10 \%$ of patients with ASD exhibit a de-novo CNV, as detected by CMA. ${ }^{11}$ Among ASD children without syndromic features, only $6 \%$ received a molecular diagnosis.

In Hong Kong, two studies have investigated the use of CMA in patients with DD, ID, ASD, or multiple congenital anomalies (MCA). Chong et al ${ }^{12}$ found clinically significant CMA results in 20 of 105 patients (19\%). Tao et $\mathrm{a}^{13}$ found a diagnostic yield of $11 \%$ for pathogenic or likely pathogenic results in 327 children, ages 1 month to $>20$ years. Excluding patients with MCA, the diagnostic yield of CMA for DD, ID, or ASD was approximately $4.2 \% .^{13}$

Chromosomal microarray has high clinical utility. Firstly, it shortens the diagnostic odyssey and may avoid unnecessary investigations, which reduces both individual and societal costs associated with testing and medical care. ${ }^{8,14}$ Secondly, it may lead to a clinically actionable recommendation. The prognostic information related to diagnosis from CMA may alert other potential co-morbid conditions that cannot be predicted on the basis of physical examination alone. In a retrospective review of 1792 patients with DD, ID, ASD, or MCA who underwent CMA testing, individuals with a positive diagnosis had a higher rate of clinical actionable recommendations than those with an uncertain result (54\% vs $34 \%, \mathrm{P}=0.01) .{ }^{15}$ In Hong Kong, a detection rate of $8.6 \%$ was reported for clinically actionable $\mathrm{CNVs},{ }^{13}$ which was comparable to the reported rates of $3.6 \%$ to $7 \%$ in Western studies. ${ }^{15-17}$ Thirdly, it allows estimation of recurrence risk and informed decisions regarding reproductive options for the parents' future pregnancies.

Children's cognitive development at $\geq 5$ years of age is more stable if the level of ID is known. Children with DD undergo assessment at CAS to facilitate their transition into primary school. Since 2012, the Clinical Genetic Service (CGS) of the Department of Health has provided CMA testing for DD, ID, or ASD. The presence of dysmorphic features, early onset of DD, increased severity of DD, and family history are common features that prompt a genetic referral. Collaboration between CAS and CGS can potentially narrow the service gap for children with DD, ID, or ASD by enabling early access to diagnostic genomic testing, thus facilitating shorter waiting time for genetic and genomic investigation(s) and a more client-friendly turnover time for results. 
The aim of this study was to investigate the genetic profile and diagnostic yield of CMA in children with moderate, severe, and profound ID. The data obtained from this study are expected to be useful in future service planning for children with DD or ID. The diagnostic yield of CMA for children with more severe forms of ID is suspected to be higher than the generally quoted figures of CMA $(10 \%)$ for investigation of ID. This study targeted children with more significant ID, which is more likely to be related to an underlying genetic aetiology.

\section{Methods}

This cross-sectional territory-wide study recruited children who attended CAS for developmental assessments, before Primary 1 entry, over a 12-month period from July 2016 to June 2017. All children were at least 5 years of age. Inclusion criteria were children with moderate, severe, or profound ID, with or without ASD. According to the International Statistical Classification of Diseases and Related Health Problems, tenth revision, ${ }^{18}$ moderate ID was defined as IQ 35 to 49; severe ID was defined as IQ 20 to 34; and profound IQ was defined as IQ $<20$. Exclusion criteria included known causes of ID: (i) antenatal causes such as congenital brain malformation or intrauterine infections; (ii) perinatal causes such as prematurity ( $<34$ weeks), birth asphyxia, or hypoxic ischaemic encephalopathy; (iii) postnatal causes such as intracranial bleeding, intracranial infection, or brain trauma; and (iv) other biological causes such as inborn errors of metabolism, brain tumour, neuromuscular disorders, neurodegenerative disorders, or cerebral palsy.

Unexplained ID in this study was defined as children with no identifiable causes for ID who did not meet any of the exclusion criteria. These children were non-syndromic and non-dysmorphic. In addition, they had neither MCA nor family history of ID or ASD among first- and second-degree relatives. The presence of MCA was defined as the involvement of two or more organ systems.

Children were assessed by paediatricians with the Griffiths Mental Developmental Scales, ${ }^{19}$ or by clinical psychologists with the Wechsler Preschool and Primary Scale of Intelligence-Revised. ${ }^{20}$ The Diagnostic and Statistical Manual of Mental Disorders, 4th edition, ${ }^{21}$ ASD diagnostic criteria were used for assessment of ASD.

\section{Genetic profile}

For children with genetic diagnoses or who were known clients of CGS, their medical files were retrieved from CAS and CGS for review. Children with syndromic or dysmorphic features, MCA, or significant family history, who had not been previously referred to CGS, were referred for a formal genetic consultation before genetic or genomic investigations were recommended by a clinical geneticist.

An expedited pathway was offered for children with unexplained ID. Pre-genetic counselling was provided by a paediatrician at CAS, followed by direct blood examination for CMA and Fragile $\mathrm{X}$ syndrome (FGX) testing at CGS. Consultation with a geneticist was arranged if either CMA or Fragile $\mathrm{X}$ testing yielded abnormal outcomes. Otherwise, clients did not consult a geneticist for further counselling.

\section{Chromosomal microarray testing and interpretation}

For each patient, $3 \mathrm{~mL}$ of blood in ethylenediaminetetraacetic acid was sent to the laboratory at CGS. All samples were tested by PerkinElmer CGX $^{\mathrm{TM}}$ v2 $60 \mathrm{~K}$ arrays designed by Agilent SurePrint technology, in accordance with the manufacturer's instructions. The coverage of the array demonstrated an average resolution of $140 \mathrm{~kb}$ across the genome, and $\leq 40 \mathrm{~kb}$ in regions of clinical relevance. It evaluated $>245$ known genetic syndromes and $>980$ gene regions of functional significance in human development. Data were analysed by Genoglyphix software (Signature Genomics, Spokane [WA], United States). Genomic coordinates were based on genome assembly hg19.

Detected CNVs were systematically evaluated for clinical significance by comparison with information in the proprietary Genoglyphix Chromosome Aberration Database (Signature Genomics), internal laboratory database at CGS and the Department of Health, and public databases (Database of Genomic Variants, International Standards for Cytogenomic Arrays Consortium, and Database of Chromosomal Imbalance and Phenotype in Humans using Ensembl Resources). Categorisation of CNVs was based on available phenotypes and comparison of phenotypes with genes in the region of copy gain or loss. This was performed by searching the following databases: Online Mendelian Inheritance in Man, PubMed, RefSeq, and the University of California Santa Cruz genome browser ${ }^{22}$ Confirmatory fluorescence in situ hybridisation (FISH), multiplex ligation-dependent probe amplification (MLPA), or conventional karyotyping was performed as indicated. Parental testing was offered to aid further interpretation and classification. Copy number variants were classified as pathogenic, likely pathogenic, uncertain clinical significance, or benign, in accordance with the 2011 American College of Medical Genetics practice guidelines. ${ }^{23}$ Only pathogenic and likely pathogenic CNVs were regarded as clinically significant.

\section{Sample size calculation}

The number of subjects to be recruited was 
estimated based on the average number of children with moderate, severe, and profound ID in the CAS database. In 2013 to 2015, the average number of children with moderate ID or worse was approximately 270 children per year. With the assumption that $60 \%$ of cases were unexplained, ${ }^{7}$ potential cases eligible for CMA were estimated as 160 children per year. Literature showed that the diagnostic yield of CMA was $10 \%$ in identifying abnormal cases in similar settings. ${ }^{13}$ A 95\% confidence interval was desired, with a reliability $(d)$ of 0.05 , in obtaining a diagnostic yield $(\hat{p})$ of $10 \%$ in this study. The sample size needed was determined following a previously published method $^{1}$ :

$$
\begin{aligned}
& n=\frac{z^{2}(\hat{p})(1-\hat{p})}{d^{2}} \\
& n=\frac{1.96^{2}(0.1)(1-0.1)}{0.05^{2}}=138
\end{aligned}
$$

Hence, a target sample size of 138 was needed. ${ }^{24}$

\section{Statistical analysis}

The genetic profile of children in the study was described. The diagnostic yield from CMA was calculated according to the severity of ID. The Freeman-Halton test was used to test associations between the severity of (a) ID and CMA and (b) dysmorphism and CMA findings. The null hypothesis was that there was no association between the severity of ID or dysmorphism and CMA findings. $\mathrm{P}<0.05$ indicated an association between the severity of ID or dysmorphism and CMA findings. The Freeman-Halton test was conducted by using SAS/ STAT 9.22.

\section{Results}

From July 2016 to June 2017, there were a total of 339 children diagnosed with more severe forms of ID: 241 (71\%) children had moderate ID, 49 (14.5\%) had severe ID, and 49 (14.5\%) had profound ID. Eighty-three children were excluded for the following reasons: (1) they met predefined exclusion criteria; (2) their family could not participate due to geographical reasons (eg, family lived in China) (3) a language barrier affected their understanding of study details (eg, the children or their families spoke primarily Nepalese or Sri Lankan); or (4) their parents could not be contacted for consent. A total of 31 children opted not to participate in the study. In all, 225 (66.4\%) of 339 children participated in the study.

Among the 225 children, 116 (51.6\%) had a co-morbid diagnosis of ASD. Male $(n=151)$ to female $(n=74)$ ratio was $2: 1$. The age ranged from 5 to 10 years old with a mean age of 6.6 years old. In all, $71.5 \%$ of children had moderate ID, $14.7 \%$ had severe ID, and $13.8 \%$ had profound ID. Two hundred twenty-one (98\%) children had Chinese parents. There were two pairs of consanguineous parents: one Indian couple and one Pakistani couple.

\section{Genetic profile of children with intellectual disability}

As shown in Table 1, 68 (30.2\%) children were diagnosed with a genetic condition. The percentage of a positive genetic diagnosis increased with the severity of ID. Chromosomal abnormalities comprised $76 \%(n=52)$ of the total genetic diagnoses. The most common syndromic diagnosis was Down syndrome $(n=22)$. There were two cases of FGX. Three children had chromosome 22 microdeletion syndromes-one exhibited the more common chromosome 22q11.2 microdeletion syndrome (DiGeorge syndrome), whereas the other two exhibited chromosome 22q13.3 deletion syndrome.

\section{Diagnostic yield of chromosomal microarray in children with intellectual disability}

Of the 225 participating children, 138 underwent CMA testing; 53 (38\%) children were referred to the Clinical Genetic Service by the expedited referral pathway. Table 2 shows that 16 (11.6\%) children demonstrated clinically significant CNVs that explained their ID phenotype and 10 (7.2\%) had variants of uncertain significance (VUS). The diagnostic yield of CMA increased with severity of ID: it was $8.7 \%$ in moderate ID, $17.6 \%$ in severe ID, and $23.5 \%$ in profound ID ( $\mathrm{P}<0.05$; Table 3$)$. Among the 16 children with clinically significant CNVs, 11 demonstrated copy number loss (deletion), four demonstrated copy number gain (duplication), and one demonstrated an unbalanced translocation between chromosome $7 q$ and $20 p$ (Table 4). One case of Angelman syndrome was detected by CMA and later confirmed with MLPA. One case of Cri du chat syndrome was detected by CMA and later confirmed with FISH. In total, $69 \%$ of pathogenic or likely pathogenic CNVs were de novo. Ten children (7.2\%) were incidentally identified as carriers of disease: six were alpha thalassemia heterozygous carriers, one was a heterozygous carrier of Joubert syndrome type 4 , one was a heterozygous carrier of autosomal recessive disease Joubert syndrome and nephronophthisis, one was a heterozygous carrier of autosomal recessive deafness affecting the $O T O A$ gene, and one was a carrier of Klinefelter syndrome.

\section{Discussion}

The overall diagnostic yield of CMA among children with ID (11.6\%) was consistent with studies performed in other regions of the world. The diagnostic yield of CMA increased with severity of ID and was much higher in children with dysmorphism (45.8\% vs $4.4 \%, \mathrm{P}<0.05)$. 
TABLE I. Genetic profile of children with ID

\begin{tabular}{|c|c|c|c|c|c|c|}
\hline Diagnosis & Affected gene & No. & Moderate & Severe & Profound & Remarks \\
\hline \multicolumn{7}{|l|}{ Chromosomal disorder } \\
\hline \multicolumn{7}{|l|}{$\begin{array}{l}\text { Gross chromosomal anomalies (diagnosed } \\
\text { by karyotype) }\end{array}$} \\
\hline Down syndrome & & 22 & 15 & 7 & & Dysmorphic \\
\hline Cri du chat syndrome & & 2 & & & 2 & Dysmorphic \\
\hline Klinefelter syndrome & & 2 & 2 & & & \\
\hline $9 p$ deletion syndrome & & 2 & 2 & & & Dysmorphic \\
\hline Chromosomal $15 q$ duplication & & 1 & 1 & & & Dysmorphic \\
\hline $\begin{array}{l}\text { Unbalanced translocation between } 1 p \\
\text { and } 9 q\end{array}$ & & 1 & & 1 & & \\
\hline $6 q 15 q 22$ deletion & & 1 & & & 1 & \\
\hline Pallister-Killian syndrome & & 1 & & & 1 & $\begin{array}{l}\text { Severe low vision, epilepsy, streaks of } \\
\text { hyperpigmentation distributed over skin } \\
\text { surface }\end{array}$ \\
\hline \multicolumn{7}{|l|}{$\begin{array}{l}\text { Microdeletion/microduplication syndrome } \\
\text { (diagnosed by karyotype) }\end{array}$} \\
\hline DiGeorge syndrome & & 1 & 1 & & & Dysmorphic \\
\hline Prader-Willi syndrome & & 1 & 1 & & & Dysmorphic \\
\hline Angelman syndrome & & 2 & & & 2 & Dysmorphic \\
\hline \multicolumn{7}{|l|}{$\begin{array}{l}\text { Microdeletion/microduplication syndrome } \\
\text { (diagnosed by CMA, see Table 4) }\end{array}$} \\
\hline Microdeletion & & 11 & 6 & 2 & 3 & \\
\hline Microduplication & & 4 & 3 & & 1 & \\
\hline Unbalanced translocation & & 1 & & 1 & & \\
\hline \multicolumn{7}{|l|}{ Single gene disorder } \\
\hline Rett syndrome & MECP2 & 3 & & & 3 & All females \\
\hline Fragile $X$ syndrome & FMR1 & 2 & & 2 & & Both with ASD \\
\hline ATRX syndrome & ATRX & 1 & & & 1 & Dysmorphic, hypotonic, squint \\
\hline $\begin{array}{l}\text { Syndromic X-linked mental retardation } \\
\text { (Christianson syndrome) }\end{array}$ & SLC9A6 & 1 & & & 1 & $\begin{array}{l}\text { Infantile-onset epileptic } \\
\text { encephalopathy, central hypotonia, } \\
\text { non-paralytic squint, autistic features }\end{array}$ \\
\hline Cardiofaciocutaneous syndrome & $B R A F$ & 2 & & 2 & & Dysmorphic, Noonan-like \\
\hline Tuberous sclerosis (AD) & TSC1/TSC2 & 2 & 1 & & 1 & \\
\hline Neurofibromatosis type 1 (AD) & $N F-1$ & 1 & 1 & & & \\
\hline Costello syndrome (AD) & HRAS & 1 & 1 & & & \\
\hline $\begin{array}{l}\text { GRIN 1-related intellectual disability } \\
\text { syndrome }\end{array}$ & GRIN 1 & 1 & & & 1 & $\begin{array}{l}\text { Ptosis, severe low vision, dystonia and } \\
\text { dyskinesia }\end{array}$ \\
\hline Mowat-Wilson syndrome (AD) & ZEB2 & 1 & & 1 & & $\begin{array}{l}\text { Cystic hygroma, severe microcephaly, } \\
\text { congenital heart disease, Hirschsprung } \\
\text { disease, epilepsy }\end{array}$ \\
\hline Coffin-Siris syndrome (AD) & $A R I D 1 B$ & 1 & 1 & & & Dysmorphic \\
\hline Total (a) & & 68 & 35 & 16 & 17 & \\
\hline Total No. in cohort based on ID severity (b) & & 225 & 161 & 33 & 31 & \\
\hline $\begin{array}{l}\text { Proportion of children with genetic } \\
\text { diagnoses }(a / b)\end{array}$ & & $30.2 \%$ & $21.7 \%$ & $48.5 \%$ & $54.8 \%$ & \\
\hline
\end{tabular}

Abbreviations: $\mathrm{AD}$ = autosomal dominant; $\mathrm{ASD}$ = autism spectrum disorder; CMA = chromosomal microarray; ID = intellectual disability

TABLE 2. Chromosomal microarray diagnostic yields in unexplained ID*

\begin{tabular}{lcccc}
\hline & Dysmorphic ID (n=24) & Non-dysmorphic ID (n=114) & Total $(\mathbf{n}=\mathbf{1 3 8})$ & P value \\
\hline Positive & $11(45.8)$ & $5(4.4)$ & $16(11.6)$ & $<0.05$ \\
VUS & $1(4.2)$ & $9(7.9)$ & $10(7.2)$ & \\
Normal & $12(50.0)$ & $90(78.9)$ & $102(74.0)$ & \\
Incidental finding & 0 & $10(8.8)$ & $10(7.2)$ & \\
\hline
\end{tabular}

Abbreviations: ID = intellectual disability; VUS = variants of uncertain significance

* Data are shown as No. (\%) 
TABLE 3. Chromosomal microarray diagnostic yields based on severity of ID*

\begin{tabular}{|c|c|c|c|c|c|}
\hline & Moderate ID $(n=104)$ & Severe ID $(n=17)$ & Profound ID $(n=17)$ & Total $(n=138)$ & $P$ value \\
\hline Positive & $9(8.7)$ & $3(17.6)$ & $4(23.5)$ & $16(11.6)$ & $<0.05$ \\
\hline VUS & $5(4.8)$ & $4(23.5)$ & $1(5.9)$ & $10(7.2)$ & \\
\hline Normal & $81(77.9)$ & 9 (52.9) & $12(70.6)$ & 102 (73.9) & \\
\hline Incidental finding & $9(8.7)$ & $1(5.9)$ & 0 & $10(7.2)$ & \\
\hline
\end{tabular}

Abbreviations: ID = intellectual disability; VUS = variants of uncertain significance

* Data are shown as No. (\%)

TABLE 4. Cases with positive chromosomal microarray results

\begin{tabular}{|c|c|c|c|c|c|c|}
\hline $\begin{array}{l}\text { Pa- } \\
\text { tient } \\
\text { No. / } \\
\text { sex }\end{array}$ & $\begin{array}{l}\text { Chromo- } \\
\text { some }\end{array}$ & Diagnosis & Genomic coordinates (hg18) of CNVs & $\begin{array}{l}\text { Pathogenic CNV size } \\
\text { and type }\end{array}$ & ID \pm ASD & $\begin{array}{l}\text { Parental } \\
\text { testing }\end{array}$ \\
\hline $1 / \mathrm{F}$ & 2 & $\begin{array}{l}\text { Chromosome } 2 q 11 \\
\text { deletion }\end{array}$ & arr[GRCh37]2q11.1q11.2(96740437_98017975) × 1 & $\begin{array}{l}1.28 \mathrm{Mb} \text { interstitial } \\
\text { deletion at } 2 \mathrm{q} 11.1 \mathrm{q} 11.2\end{array}$ & Moderate & De novo \\
\hline $2 / M$ & 3 & $\begin{array}{l}\text { Chromosome } 3 q 13.31 \\
\text { microdeletion syndrome }\end{array}$ & $\operatorname{arr}[$ hg19]3q13.31(113,525,219-115,303,006) × 1 & $\begin{array}{l}1.78 \mathrm{Mb} \text { interstitial } \\
\text { deletion at } 3 \mathrm{q} 13.31\end{array}$ & Moderate & De novo \\
\hline $3 / F$ & 5 & $\begin{array}{l}\text { Chromosome } 5 \mathrm{p} 15.2 \\
\text { microdeletion syndrome } \\
\text { (Cri du chat syndrome) }\end{array}$ & $\begin{array}{l}\text { arr[hg18]5p15.2(9,029,310-11,382,195) × } \\
\text { arr[hg18]3p26.1 }\end{array}$ & $\begin{array}{l}2.35 \mathrm{Mb} \text { interstitial } \\
\text { deletion at } 5 \mathrm{p} 15.2 \\
132.29 \mathrm{~Kb} \text { interstitial } \\
\text { deletion at 3p26.1 }\end{array}$ & Profound* & De novo \\
\hline $4 / M$ & 6 & $\begin{array}{l}\text { Chromosome } \\
6 q 21 q 22.31 \text { deletion }\end{array}$ & arr[hg19]6q21q22.31(113,282,465-119,803,338) × 1 & $\begin{array}{l}6.52 \mathrm{Mb} \text { interstitial } \\
\text { deletion at } 6 \mathrm{q} 21 \mathrm{q} 22.3\end{array}$ & Moderate & $\mathrm{N}$ \\
\hline $5 / M$ & 7 & $\begin{array}{l}\text { Unbalanced } \\
\text { translocation between } \\
7 q \text { and } 20 p\end{array}$ & $\begin{array}{l}\text { arr[hg19]7q36.1q36.3(150,115,362-159,123,167) × } 1 \\
20 p 13 p 12.3(71,023-5,101,414) \times 3\end{array}$ & $\begin{array}{l}\text { 9.01 Mb terminal copy } \\
\text { loss at } 7 \mathrm{q} 36.1 \mathrm{q} 36.3 \\
5.03 \mathrm{Mb} \text { terminal copy } \\
\text { gain at 20p13-p12.3 }\end{array}$ & Severe* $^{*}$ & De novo \\
\hline $6 / \mathrm{M}$ & 7 & $\begin{array}{l}\text { Chromosome } \\
7 q 35 q 36.2 \text { deletion }\end{array}$ & $\operatorname{arr}[\mathrm{hg} 19] 7 q 35 q 36.2(145,379,142-153,653,280) \times 1$ & $\begin{array}{l}8.27 \mathrm{Mb} \text { interstitial } \\
\text { deletion at } 7 \mathrm{q} 35 \mathrm{q} 36.2\end{array}$ & Moderate* & De novo \\
\hline $7 / \mathrm{F}$ & 11 & $\begin{array}{l}\text { Chromosome 11p11.2 } \\
\text { deletion }\end{array}$ & $\operatorname{arr}[\mathrm{hg} 19] 11 \mathrm{p} 11.2(45,108,173-48,388,756) \times 1$ & $\begin{array}{l}3.28 \mathrm{Mb} \text { interstitial } \\
\text { deletion at } 11 \mathrm{p} 11.2\end{array}$ & Profound $^{*}$ & De novo \\
\hline $8 / \mathrm{M}$ & 12 & $\begin{array}{l}\text { Chromosome } 12 q 23 \\
\text { deletion, alpha thal } \\
\text { carrier }\end{array}$ & $\begin{array}{l}\operatorname{arr}[\text { hg19]12q23.1q23.3(98,094,511-104,810,413) × } \\
16 p 13.3(215,499-232,686) \times 1\end{array}$ & $\begin{array}{l}6.72 \mathrm{Mb} \text { interstitial } \\
\text { deletion at } 12 \mathrm{q} 23.1 \mathrm{q} 23.3 \\
17.19 \mathrm{~Kb} \text { interstitial } \\
\text { deletion at } 16 \mathrm{p} 13.3\end{array}$ & Moderate & De novo \\
\hline $9 / \mathrm{F}$ & 14 & $\begin{array}{l}\text { 14q11.2 Microdeletion } \\
\text { syndrome }\end{array}$ & $\operatorname{arr}[$ hg19]14q11.2(21,821,702-21,916,153) × 1 & $\begin{array}{l}94.45 \mathrm{~Kb} \text { interstitial } \\
\text { deletion at } 14 \mathrm{q} 11.2\end{array}$ & $\begin{array}{l}\text { Severe + } \\
\text { ASD* }^{*}\end{array}$ & $\mathrm{~N}$ \\
\hline $10 / M$ & 15 & $\begin{array}{l}15 q 11.2 q 13.1 \\
\text { Microdeletion (Angelman } \\
\text { syndrome) }\end{array}$ & $\operatorname{arr}[\mathrm{hg} 19] 15 \mathrm{q} 11.2 \mathrm{q} 13.1(22,822,019-28,513,166) \times 1$ & $\begin{array}{l}5.69 \mathrm{Mb} \text { interstitial } \\
\text { deletion at } \\
15 q 11.2-q 13.1\end{array}$ & Profound ${ }^{\star}$ & De novo \\
\hline $11 / F$ & 15 & $\begin{array}{l}\text { 15q11.2-13.3 } \\
\text { Duplication syndrome }\end{array}$ & $\begin{array}{l}\operatorname{arr}[\mathrm{hg} 19] 15 q 11.2 q 13.3(22,822,019-32,427,979) \times 3 \\
15 q 13.2 q 13.3(31,140,606-32,427,979) \times 3\end{array}$ & $\begin{array}{l}9.61 \mathrm{Mb} \text { copy gain at } \\
15 \mathrm{q} 11.2-\mathrm{q} 13.3 \\
1.29 \mathrm{Mb} \text { copy gain at } \\
15 \mathrm{q} 13.2-13.3\end{array}$ & Moderate $^{\star}$ & De novo \\
\hline $12 / \mathrm{M}$ & 16 & $\begin{array}{l}16 \mathrm{p} 13.11 \\
\text { Microduplication } \\
\text { syndrome }\end{array}$ & 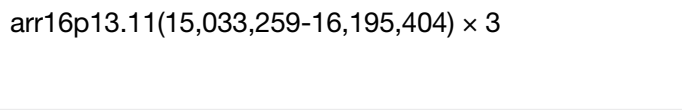 & $\begin{array}{l}1.16 \mathrm{Mb} \text { interstitial } \\
\text { duplication at } 16 \mathrm{p} 13.11\end{array}$ & Moderate* & Mat \\
\hline $13 / F$ & 16 & $\begin{array}{l}16 p 13.11 \\
\text { Microduplication } \\
\text { syndrome }\end{array}$ & $\operatorname{arr}[\mathrm{hg} 19] 16 \mathrm{p} 13.11(15,125,829-16,287,900) \times 3$ & $\begin{array}{l}1.16 \mathrm{Mb} \text { interstitial } \\
\text { duplication at } 16 \mathrm{p} 13.11\end{array}$ & Profound ${ }^{*}$ & Mat \\
\hline $14 / \mathrm{M}$ & 19 & 19p13.3 Duplication & arr19p13.3(1,044,712-1,972,214) × 3 & $\begin{array}{l}\text { Interstitial duplication at } \\
19 p 13.3\end{array}$ & Moderate* & De novo \\
\hline $15 / F$ & 22 & $\begin{array}{l}\text { Chromosome } \\
\text { 22q13.31q13.33 deletion }\end{array}$ & $\begin{array}{l}\operatorname{arr}[\mathrm{hg} 18] 22 \mathrm{q} 13.31 \mathrm{q} 13.33(45,355,784-49,522,658) \times 1 \\
X \times 2\end{array}$ & $\begin{array}{l}4.17 \mathrm{Mb} \text { terminal deletion } \\
\text { at } 22 \mathrm{q} 13.31 \mathrm{q} 13.33\end{array}$ & Moderate & De novo \\
\hline $16 / F$ & 22 & $\begin{array}{l}\text { Chromosome } \\
\text { 22q13.31q13.33 deletion }\end{array}$ & $\operatorname{arr}[G R C h 37] 22 q 13.31 q 13.33(47807636-51178150) \times 1$ & $\begin{array}{l}\text { 3.37 Mb terminal deletion } \\
\text { at } 22 \mathrm{q} 13.31 \mathrm{q} 13.33\end{array}$ & Severe $^{*}$ & $\mathrm{~N}$ \\
\hline
\end{tabular}

Abbreviations: $\mathrm{ASD}=$ autism spectrum disorder; $\mathrm{CNV}=$ copy number variant; ID = intellectual disability; Mat = maternal inheritance; $\mathrm{N}=$ not tested

* Dysmorphism 
Variants of uncertain significance are not uncommon. In all, $7.2 \%$ of children in this cohort had VUS (Table 5). Regular follow-up and reassessment by a clinical geneticist is necessary for these children, because VUS may eventually be re-classified as pathogenic or benign as clinical and genomic data accumulate in the literature.

The paradigm shift in the medical genetic and genomic field from the phenotype-first approach to the genotype-first approach is revolutionary. Traditionally, a phenotype-first approach was used to guide the investigation of possible genetic diagnoses, eg, karyotyping for Down syndrome, or specific assays, such as FISH, for DiGeorge syndrome. In the past decade, CMA has allowed more comprehensive unbiased discovery of microdeletion and microduplication syndromes throughout the human genome. Since the 1980s, it has been wellknown that certain chromosomal microdeletion and microduplication syndromes are associated with recognisable forms of ID and DD. Classical examples include 15q11-q13 deletion, associated with PraderWilli and Angelman syndromes, and 22q11.2 deletion, associated with DiGeorge syndrome (velocardiofacial syndrome). Thus far, approximately 50 to 60 recurrent microdeletion or duplication syndromes have been identified in children with DD or ID.

Although CMA is robust, it cannot replace a formal genetic consultation for children with clinically suspected genetic conditions. As an example, in Prader-Willi syndrome, $70 \%$ to $75 \%$ of cases can be detected by CMA, as they are due to a paternal 15q microdeletion subtype; $20 \%$ to $25 \%$ of cases require a more specific methodology for genetic confirmation. Therefore, clinical correlation and expert assessment remain necessary.

Males are more susceptible to ID than females; more than $100 \mathrm{X}$-linked genes are associated with ID. ${ }^{25} \mathrm{X}$-linked ID constitutes $5 \%$ to $10 \%$ of ID in males. One of the best-known causative genes for ID is FMR1; mutations of FMR1 result in FGX. The estimated incidence of FGX is approximately 1 in 4000 males and 1 in 5000 to 1 in 8000 females (approximately $0.5 \%$ of cases of ID) in Western countries. Peprah ${ }^{26}$ reported that the incidence of FGX in countries/regions with significant Asian populations, such as Canada, Estonia, Japan, and Taiwan, was significantly lower than in Western countries. In a study of 553 male children between the ages of 6 months and 18 years, Chen et $\mathrm{al}^{27}$ estimated the prevalence of FGX in mainland China

TABLE 5. Cases with variants of uncertain significance

\begin{tabular}{|c|c|c|c|c|c|}
\hline $\begin{array}{l}\text { Pa- } \\
\text { tient } \\
\text { No. / } \\
\text { sex }\end{array}$ & $\begin{array}{l}\text { Chromosomal microarray } \\
\text { result }\end{array}$ & Genomic coordinates of CNVs & OMIM gene & ID \pm ASD & $\begin{array}{c}\text { Parental } \\
\text { testing }\end{array}$ \\
\hline $1 / \mathrm{M}$ & Interstitial deletion at $1 \mathrm{q} 31.2$ & arr[hg19] 1q31.2(192,211,309-192,842,253) × 1 & RGS21, RGS1, RGS13, RGS2 & $\begin{array}{c}\text { Moderate + } \\
\text { ASD }\end{array}$ & De novo \\
\hline $2 / F$ & $\begin{array}{l}\text { Interstitial deletion at } 2 \mathrm{p} 22.1 \\
\text { copy number gain at } 8 \mathrm{q} 13.3 \\
\text { interstitial deletion at } 16 \mathrm{q} 22.1\end{array}$ & $\begin{array}{l}\text { arr[hg19] 2p22.1(39,741,176-40,107,142) × } \\
8 \mathrm{q} 13.3(72,922,285-73,414,414) \times 3 \\
16 \mathrm{q} 22.1(69,937,248-70,302,476) \times 1\end{array}$ & $\begin{array}{l}\text { THUMPD2, TRPA1, WWP2, } \\
\text { MIR140, CLEC18A, } \\
\text { CLEC18C, EXOSC6, AARS }\end{array}$ & $\begin{array}{l}\text { Severe + } \\
\text { ASD }\end{array}$ & De novo \\
\hline $3 / \mathrm{M}$ & Interstitial deletion at $2 \mathrm{q} 24.3$ & $\operatorname{arr}[G R C h 37]$ 2q24.3(165494643_166207407) × 1 & $\begin{array}{l}\text { COBLL1, SLC38A11, SCN3A, } \\
\text { SCN2A }\end{array}$ & $\begin{array}{l}\text { Moderate + } \\
\quad \text { ASD }\end{array}$ & De novo \\
\hline $4 / \mathrm{M}$ & Copy number gain at $2 q 31.1$ & $\operatorname{arr}[$ hg19] 2q31.1(176,947,511-177,055,079) $\times 3$ & $\begin{array}{l}\text { EVX2, HOXD13, HOXD12, } \\
\text { HOXD11, HOXD10, HOXD9, } \\
\text { HOXD8, MIR10B, HOXD4, } \\
\text { HOXD3, HOXD1 }\end{array}$ & $\begin{array}{l}\text { Moderate + } \\
\quad \text { ASD }\end{array}$ & De novo \\
\hline $5 / M$ & Interstitial deletion at $4 \mathrm{q} 32.1$ & $\operatorname{arr}[G R C h 37]$ 4q32.1(158045745_159876096) × 1 & $\begin{array}{l}\text { GLRB, GRIA2, RXFP1, } \\
\text { C4orf46, ETFDH, PPID, FNIP2 }\end{array}$ & $\begin{array}{l}\text { Moderate + } \\
\text { ASD }\end{array}$ & $\mathrm{N}$ \\
\hline $6 / \mathrm{M}$ & Interstitial deletion at $4 \mathrm{q} 22.1$ & $\operatorname{arr}[\mathrm{GRCh37]}$ 4q22.1(91161691_91618811) × 1 & CCSER1 & Severe & $\mathrm{N}$ \\
\hline $7 / \mathrm{M}$ & Copy number gain at $5 \mathrm{p} 13.33$ & arr[hg19] 5p15.33(445,144-990,819) × 3 & $\begin{array}{l}\text { EXOC3, SLC9A3, CEP72, } \\
\text { TPPP, TRIP13 }\end{array}$ & $\begin{array}{l}\text { Severe + } \\
\quad \text { ASD }\end{array}$ & De novo \\
\hline $8 / \mathrm{M}$ & $\begin{array}{l}\text { Interstitial deletion at } \\
6 \mathrm{p} 21.1 \mathrm{p} 12.3\end{array}$ & $\operatorname{arr}[$ GRCh37] 6p21.1p12.3(45972996_46745796) × 1 & $\begin{array}{l}\text { CLIC5, ENPP4, ENPP5, } \\
\text { RCAN2, CYP39A1, } \\
\text { SLC25A27, TDRD6, PLA2G7 }\end{array}$ & $\begin{array}{l}\text { Moderate + } \\
\quad \text { ASD }\end{array}$ & De novo \\
\hline $9 / M$ & $\begin{array}{l}\text { Copy number gain at } \\
7 \mathrm{p} 21.2-\mathrm{p} 21.3\end{array}$ & arr[hg18] 7p21.3p21.2(12,155,874-13,472,985) × 3 & TMEM106B, SCIN, ARL4A & Profound $^{*}$ & Pat \\
\hline $10 / F$ & Copy number gain at $20 \mathrm{q} 11.21$ & $\operatorname{arr}[$ hg18] 20q11.21(29,542,526-29,579,598) × 3 & HM13 & Severe & Mat \\
\hline
\end{tabular}

Abbreviations: $\mathrm{ASD}=$ autism spectrum disorder; CNV = copy number variant; ID = intellectual disability; Mat = maternal inheritance; $N=$ not tested; OMIM = Online Mendelian Inheritance in Man; Pat = paternal inheritance

* Dysmorphism 
to be approximately $0.93 \%$ among children with moderate to severe ID. Among the 225 children in our cohort, only two were diagnosed with FGX. Both exhibited ASD and severe ID. The typical physical characteristics of FGX, such as narrow face, protruding ears, and macro-orchidism, are often less obvious in early childhood; notably, they may become more prominent as the child approaches adolescence. This lack of early physical characteristics increases the diagnostic challenge for clinicians. Fragile $\mathrm{X}$ syndrome testing, regarded as first-tier genetic testing for DD and ASD in many international guidelines, has been a standard genetic investigation for ID or ASD in Hong Kong for many years.

Incomplete penetrance of a genomic condition within the same family is not uncommon. Notably, there were two such cases of 16p13.11 microduplication syndrome in this cohort. Patient 12 (Table 4) exhibited subtle dysmorphism comprising downslanting palpebral fissures, prominent ears, and mild right ptosis. Left undescended testes and umbilical hernia were operated in infancy. $\mathrm{He}$ exhibited global DD and was later diagnosed with moderate ID. His mother and two sisters had an identical chromosomal defect, but exhibited normal intelligence. Patient 13 demonstrated a more severe phenotype with hirsutism, bushy eyebrows, frontal bossing, hearing loss, visual problems, and profound ID. His mother and elder brother, both carrying the microduplication, exhibited normal intelligence. There likely exist unknown environmental or genetic modifiers to modulate susceptibility to ID caused by this microduplication. Thus, relying on family history to determine whether ID is hereditary can be misleading.

An important aspect with respect to obtaining a genetic diagnosis is patient prognosis. The $16 \mathrm{p} 13.11$ duplication syndrome is associated with an aortic root defect. In this study, the two affected children and their affected family members were referred for monitoring by echocardiogram. Similarly, Patient 2 exhibited 3q13.31 microdeletion syndrome, which is associated with diabetes mellitus and deafness; this patient was referred for audiological assessment and counselled on lifestyle management to minimise the risk of diabetes. In this study, three of 16 CMApositive cases (18.8\%) were clinically actionable.

Pre-test genetic counselling is as important as post-test counselling. Coincidental findings of genetic changes that either predict adult-onset conditions or reveal carrier status for recessive or Xlinked conditions are common. In the present cohort, 10 children were identified as carriers of genetic conditions, including one child diagnosed with Klinefelter syndrome. He presented with moderate ID and ASD. Chromosomal microarray identified a copy number gain of the entire $\mathrm{X}$ chromosome. Klinefelter syndrome can be associated with learning disabilities, as well as delayed speech and language development. While a small, but significant, downward shift in mean overall IQ has been reported, general cognitive abilities of patients with Klinefelter syndrome are not typically in the ID range. ${ }^{28}$ An extra $\mathrm{X}$ chromosome may have contributed partially, but could not entirely explain the severity of ID. The major implications are that individuals with Klinefelter syndrome have a higher risk of endocrine dysfunction, fertility problems, male breast cancer, and autoimmune disease.

This study provided important information with respect to service planning for children with ID in Hong Kong. It allowed testing of an expedited referral mechanism between CAS and CGS, in which cases with unexplained ID benefitted through a significant reduction of waiting time for both pre-testing genetic counselling and investigation turnover time. This study included $38 \%$ of the 138 children who were not referred to CGS. The ideal future approach may be to extend the expedited mechanism for children with early-onset significant DD. It can avoid unnecessary investigations, thus lowering stress for both child and parent; importantly, it may reduce societal costs.

There were several limitations in this study. Firstly, a complete genetic profile of ID was not generated, as this cohort excluded mild ID. Secondly, clients from minority cultural groups in Hong Kong were underrepresented, because the language barrier affected recruitment. More effort must be expended to ensure equal opportunities for children from diverse cultural backgrounds. Thirdly, the duration of the study was of insufficient length for commentary on trends regarding the genetic profile of ID in Hong Kong.

\section{Conclusion}

The overall diagnostic yield (11.6\%) of CMA is compatible with other international cohorts. Chromosomal microarray yield increases with the severity of ID. These data further support the use of CMA as a first-tier investigation for children with significant unexplained ID in Hong Kong.

\section{Author contributions}

All authors have made substantial contributions to the concept or design of the study, acquisition of data, analysis or interpretation of data, drafting of the article, and critical revision for important intellectual content.

\section{Acknowledgement}

The authors would like to thank Mr Morris Wu of Child Assessment Service, Department of Health for his advice on the statistical analysis of the data. 


\section{Declaration}

The authors have no conflicts of interest to disclose. All authors had full access to the data, contributed to the study, approved the final version for publication, and take responsibility for its accuracy and integrity.

\section{Funding/support}

This research received no specific grant from any funding agency in the public, commercial, or not-for-profit sectors.

\section{Ethical approval}

Approval was obtained from the Ethics Committee of the Department of Health, Hong Kong Special Administrative Region. Informed consent was obtained from parents or legal guardians. Parents and legal guardians were counselled about the indication for CMA, benefits and limitations of test, methodology, reporting time, and possible outcomes upon recruitment.

\section{References}

1. Leonard $\mathrm{H}, \mathrm{Wen} \mathrm{X}$. The epidemiology of mental retardation: challenges and opportunities in the new millennium. Ment Retard Dev Disabil Res Rev 2002;8:117-34.

2. Social Data Collected via the General Household Survey. Special Topics Report No 62. Persons with Disabilities and Chronic Diseases. Hong Kong: Census and Statistics Department, Hong Kong SAR Government; 2014.

3. American Association on Intellectual and Developmental Disabilities. Intellectual Disability: Definition, Classification, and Systems of Supports. 11th ed. Washington, DC: American Association on Intellectual and Developmental Disabilities;2010: xvi, 259.

4. Moeschler JB, Shevell M, Committee on Genetics. Comprehensive evaluation of the child with intellectual disability or global developmental delays. Pediatrics 2014;134:e903-18.

5. Tang KM, Chen TY, Lau VW, Wu MM. Clinical profile of young children with mental retardation and developmental delay in Hong Kong. Hong Kong Med J 2008;14:97-102.

6. Willemsen $\mathrm{MH}$, Kleefstra T. Making headway with genetic diagnostics of intellectual disabilities. Clin Genet 2014;85:101-10.

7. Rauch A, Hoyer J, Guth S, et al. Diagnostic yield of various genetic approaches in patients with unexplained developmental delay or mental retardation. Am J Med Genet A 2006;140:2063-74.

8. Michelson DJ, Shevell MI, Sherr EH, Moeschler JB, Gropman AL, Ashwal S. Evidence report: Genetic and metabolic testing on children with global developmental delay: report of the Quality Standards Subcommittee of the American Academy of Neurology and the Practice Committee of the Child Neurology Society. Neurology 2011;77:1629-35.

9. Miller DT, Adam MP, Aradhya S, et al. Consensus statement: chromosomal microarray is a first-tier clinical diagnostic test for individuals with developmental disabilities or congenital anomalies. Am J Hum Genet 2010;86:749-64.

10. Tammimies K, Marshall CR, Walker S, et al. Molecular diagnostic yield of chromosomal microarray analysis and whole-exome sequencing in children with autism spectrum disorder. JAMA 2015;314:895-903.

11. Sebat J, Lakshmi B, Malhotra D, et al. Strong association of de novo copy number mutations with autism. Science 2007;316:445-9.

12. Chong WW, Lo IF, Lam ST, et al. Performance of chromosomal microarray for patients with intellectual disabilities/developmental delay, autism, and multiple congenital anomalies in a Chinese cohort. Mol Cytogenet 2014;7:34.

13. Tao VQ, Chan KY, Chu YW, et al. The clinical impact of chromosomal microarray on paediatric care in Hong Kong. PLoS One 2014;9:e109629.

14. Tirosh E, Jaffe M. Global developmental delay and mental retardation-a pediatric perspective. Dev Disabil Res Rev 2011;17:85-92.

15. Coulter ME, Miller DT, Harris DJ, et al. Chromosomal microarray testing influences medical management. Genet Med 2011;13:770-6.

16. Ellison JW, Ravnan JB, Rosenfeld JA, et al. Clinical utility of chromosomal microarray analysis. Pediatrics 2012;130:e1085-95.

17. Riggs ER, Wain KE, Riethmaier D, et al. Chromosomal microarray impacts clinical management. Clin Genet 2014;85:147-53.

18. World Health Organization. The ICD-10 classification of mental and behavioural disorders: diagnostic criteria for research: Geneva: World Health Organization; 1993.

19. Luiz D, Barnard A, Knosen N, Kotras N, Faragher B, Burns LE. Griffiths Mental Development Scales-Extended Revised. Two to Eight Years. Administration Manual. Oxford, UK: Hogrefe; 2006.

20. Wechsler D. Wechsler Preschool and Primary Scale of Intelligence-Revised. WPPSI-R: Psychological Corporation; 1989.

21. Diagnostic and Statistical Manual of Mental Disorders: DSM-IV. Washington, DC: American Psychiatric Association;1994: 535.

22. Kan AS, Lau ET, Tang WF, et al. Whole-genome array CGH evaluation for replacing prenatal karyotyping in Hong Kong. PLoS One 2014;9:e87988.

23. Kearney HM, Thorland EC, Brown KK, et al. American College of Medical Genetics standards and guidelines for interpretation and reporting of postnatal constitutional copy number variants. Genet Med 2011;13:680-5.

24. Boada R, Janusz J, Hutaff-Lee C, Tartaglia N. The cognitive phenotype in Klinefelter syndrome: a review of the literature including genetic and hormonal factors. Dev Disabil Res Rev 2009;15:284-94.

25. Lubs HA, Stevenson RE, Schwartz CE. Fragile X and Xlinked intellectual disability: four decades of discovery. Am J Hum Genet 2012;90:579-90.

26. Peprah E. Fragile X syndrome: the FMR1 CGG repeat distribution among world populations. Ann Hum Genet 2012;76:178-91.

27. Chen X, Wang J, Xie $\mathrm{H}$, et al. Fragile $\mathrm{X}$ syndrome screening in Chinese children with unknown intellectual developmental disorder. BMC Pediatr 2015;15:77.

28. Daniel WW. Biostatistics: A Foundation for Analysis in the Health Sciences. 9th ed. Hoboken, NJ: J Wiley \& Sons; 2009. 